\title{
Hybrid optimization model for conjunctive use of surface and groundwater resources in water deficit irrigation system
}

\author{
Karthikeyan MoothampalayamSampathkumar1,* , Saravanan Ramasamy ${ }^{1}$, Balamurugan Ramasubbu ${ }^{1}$, Hamid Reza \\ Pourghasemi $^{2}$, Saravanan Karuppanan ${ }^{1}$ and Balaji Lakshminarayanan ${ }^{1}$ \\ ${ }^{1}$ Centre for Water Resources, Anna University, Chennai, India \\ rsaran@annauniv.edu (S.R.); mrbals@annauniv.edu (B.R.); ksarancwr@annauniv.edu.in (S.K); \\ balajicwr@annauniv.edu.in (B.L.); \\ 2 Department of Natural Resources and Environmental Engineering, College of Agriculture, Shiraz University, \\ Shiraz 71441-65186, Iran; hr.pourghasemi@shirazu.ac.ir (H.R.P.) \\ * Correspondence: msk@annauniv.edu(K.M.);
}

\begin{abstract}
Increasing demand for food production with limited available water resources pose the threat to agricultural activities. The conjunctive allocation of water resources maximizes the net benefit of farmers efficiently. In this study, a novel hybrid optimization model was developed based on a genetic algorithm (GA), bacterial foraging optimization (BFO) and ant colony optimization (ACO) to maximize the net benefit of water deficit Sathanur reservoir command. The GA-based optimization model considered crop-related physical and economical parameters to derive optimal cropping patterns for three different conjunctive use policies and further allocation of surface and groundwater for different crops are enhanced with the BFO. The allocation of surface and groundwater for the head, middle and tail reach obtained from BFO is considered as input to ACO as a guiding mechanism to attain an optimal cropping pattern. Comparing the average productivity values Policy 3 (3.665 Rs $\left./ \mathrm{m}^{3}\right)$ has better values relating to Policy $1\left(3.662 \mathrm{Rs} / \mathrm{m}^{3}\right)$ and Policy $2\left(3.440 \mathrm{Rs} / \mathrm{m}^{3}\right)$. Thus, the developed novel hybrid optimization model (GA-BFO-ACO) is very promising to enhance the farmer's net income as well as for the command area water conservation and can be replicated in other irrigated regions of the globe to overcome chronic land and water problems.
\end{abstract}

Keywords: conjunctive use; cropping pattern; genetic algorithm; bacterial foraging optimization; ant colony optimization; hybrid optimization; productivity

\section{Introduction}

Population increment and demand for food resources impose a serious threat to water resources, as a $60 \%$ increase in food requirement is expected in the year 2050[1]. Climate change increased the rainfall intensity and reduced the number of rainy days in an occurring year which leads to flood and drought without proper management of available rainfall which pose risk to human lives[2]. In many developing nations $90 \%$ of water withdrawn for irrigation purposes and extraction of groundwater about $15-35 \%$ for irrigation 
are assessed as unsustainable [3]. Conjunctive use of surface and groundwater in an irrigation system should be taken up to avoid drawdown of groundwater levels and to avoid water stress. The main purpose of conjunctive use of available water resources is to increase the yield and reliability without compromising supply [4]. The key benefits of conjunctive use are maximizing the net return by minimizing the water stress of the crop. It is necessary to use a suitable cropping pattern that maximizes the net profit for the available conjunctive water. The optimal allocation of surface and groundwater resources at the different cropping seasons of the year is crucial in conjunctive planning[5].Different programming methods have been used in the optimization of conjunctive use of surface and groundwater for irrigation planning and discussed extensively in [4]. Previous studies that examined different programming techniques in optimization of conjunctive use are Linear Programming[6][7], Non-linear Programming[8][9], and Dynamic Programming[10][11]. However, the inability to attain the global solution and handle non-linear non-convex problems requires a heuristic approach. Genetic algorithms (GA) have been used in several studies for solving the non-convex problem to attain a global optimal solution in conjunctive use. Some of the key studies which employed a heuristic approach in the optimization of conjunctive resources for maximizing net benefit are mentioned in Table 1.

Table 1. Summary of key studies employed heuristic approach for conjunctive use

\begin{tabular}{|c|c|c|}
\hline Citation & $\begin{array}{c}\text { Optimization Method } \\
\text { / Algorithm }\end{array}$ & Inference \\
\hline [12] & $\begin{array}{l}\text { Jaya algorithm and } \\
\text { Particle swarm } \\
\text { optimization }\end{array}$ & $\begin{array}{l}\text { Net annual returns improved by } 76 \% \text { and } 78 \% \text { for PSO and Jaya algo- } \\
\text { rithm respectively from the existing cropping pattern also water alloca- } \\
\text { tion reduced by } 39 \% \text { for PSO and Jaya algorithm. }\end{array}$ \\
\hline [13] & $\begin{array}{l}\text { Elitist Jaya algorithm } \\
\text { (EJA) and Elitist teach- } \\
\text { ing learning-based op- } \\
\text { timization (ETLBO) }\end{array}$ & $\begin{array}{l}\text { EJA was found to be a better algorithm when compared with ETLBO, } \\
\text { JA, TLBO, and Linear programming (LP). For maximum cropping pat- } \\
\text { tern net benefit results of EJA perform better than LP, ETLBO, TLBO, } \\
\text { and JA as } 8.33 \%, 0.04 \%, 0.58 \% \text {, and } 0.002 \% \text { respectively. }\end{array}$ \\
\hline [14] & $\begin{array}{l}\text { Self-adaptive multi- } \\
\text { population Jaya algo- } \\
\text { rithm (SAMP-JA) }\end{array}$ & $\begin{array}{l}\text { SAMP-JA was compared with PSO, DE, IWO, FA, TLBO, JA, elitist-JA } \\
\text { and elitist-TLBO. Net annual benefits were found the same for SAMP- } \\
\text { JA and EJA. The rate of convergence was found better in SAMP-JA than } \\
\text { EJA. }\end{array}$ \\
\hline [15] & $\begin{array}{l}\text { Cuckoo Search algo- } \\
\text { rithm }\end{array}$ & $\begin{array}{l}\text { The cropping pattern suggested by cuckoo search increase the net bene- } \\
\text { fits by } 33 \% \text { and LINDO provides a } 21 \% \text { increment than the existing } \\
\text { cropping pattern. }\end{array}$ \\
\hline [16] & $\begin{array}{l}\text { Linear programming } \\
\text { (LP), Genetic algo- } \\
\text { rithm (GA), Cuckoo } \\
\text { search (CS) and Parti- } \\
\text { cle swarm optimiza- } \\
\text { tion (PSO). }\end{array}$ & $\begin{array}{l}\text { The maximum net return found by PSO optimized cropping pattern re- } \\
\text { sults in } 230.120 \text { billion rupees whereas GA, CS and LP produce } 210.19 \\
\text { billion rupees, } 229.895 \text { billion rupees and } 199.271 \text { billion rupees respec- } \\
\text { tively. The optimized cropping produced from swarm techniques re- } \\
\text { sults in } 97.92 \text { billion rupees more than the existing cropping pattern. }\end{array}$ \\
\hline [17] & $\begin{array}{l}\text { Cuckoo optimization } \\
\text { algorithm (COA) and } \\
\text { Genetic algorithm } \\
\text { (GA) }\end{array}$ & $\begin{array}{l}\text { COA algorithm performs better than GA in terms of net benefit and low } \\
\text { water consumption. The net profit increased by } 1.48 \%, 1.27 \%, 2.6 \% \text {, } \\
6.2 \% \text { respectively in hot-dry, dry, normal and wet conditions. }\end{array}$ \\
\hline
\end{tabular}


[18] Genetic algorithm (GA)

\begin{abstract}
Conjunctive use of surface and groundwater resources is optimized using a genetic algorithm (GA) for two scenarios. For scenario - I, 24

MCM of water was saved with a reduction in net financial return by $22 \%$. For scenario- II, the net revenue increased in dry years when compared with normal and wet years.
\end{abstract}

However, as discussed in the literature much of the early work centers around the comparison of meta-heuristic algorithm performance in the optimization of cropping patterns which maximize the net benefits of farmers. In this study, a novel hybrid optimization approach is employed for the conjunctive use of surface and groundwater to maximize the economic benefit by optimizing cropping patterns. Considering the effectiveness of meta-heuristic algorithms, a hybrid optimization model which comprises of Genetic Algorithm (GA), Bacterial Foraging Optimization (BFO) and Ant Colony Optimization (ACO) was developed. The developed model would maximize the farmers' net benefit by conjunctively using the surface water from reservoir release and groundwater resources at the head, middle and tail reach of the Sathanur reservoir command for three different cropping seasons. The developed model comprises of three stages i) Cropping area optimization based on genetic algorithm ii) Optimization of surface and groundwater allocation conjunctively using BFO iii) Maximizing the net benefit of farmers using ACO.

\section{Materials and Methods}

\subsection{Study Area}

Sathanur reservoir command located in Tiruvannamalai district, Tamil Nadu, India was selected for this study which lies between the coordinates of $11^{\circ} 55^{\prime} \mathrm{N}$ and $12^{\circ} 05^{\prime} \mathrm{N}$ latitude and 78 $55^{\prime} \mathrm{E}$ and $79^{\circ} 00^{\prime} \mathrm{E}$ longitude. The geographical area covers approximately $18,200 \mathrm{ha}$. The Sathanur Reservoir has a capacity of $207.3 \mathrm{Mm} 3$ and the catchment area is $10,835 \mathrm{~km} 2$. The total cultivable area under the Sathanur command is divided into Sathanur Left Bank Canal (SLBC) and Right Bank Canal (SRBC) with an extent of 10,200 ha and 8,000 ha respectively.The command area's average topographical gradient is 2.5 meters per $\mathrm{km}$. The annual average rainfall of the study area is $1040 \mathrm{~mm}$ and the climate is tropical withtemperature ranges between maximum $\left(29.5^{\circ} \mathrm{C}\right.$ to $\left.38.4^{\circ} \mathrm{C}\right)$ and minimum $\left(20.4^{\circ} \mathrm{C}\right.$ to $\left.26.5^{\circ} \mathrm{C}\right)[19]$. Red loamy is predominant soil formation in the study area and geological formations are comprised of charnockites and gneiss majorly. Paddy, sugarcane, pulses and groundnuts are the major crops cultivated in the Sathanur command area.

Paddy is the main crop grown in the irrigation command area for Season-1 (AugustNovember). During Season-2 (December-March), groundnuts, maize, and grains are grown. In Season-3 (April-July), paddy, groundnuts, and pulses are grown. Sugarcane is also grown relatively in the command area. These are the cropping pattern followed in the Sathanur command area. Cropping plans, present reservoir capacity, and profit/ha for various crops were obtained from the Public Works Department and Agricultural Department, Thiruvannamalai District, Tamil Nadu, India. The map indicating the study area is represented in Figure 1. 

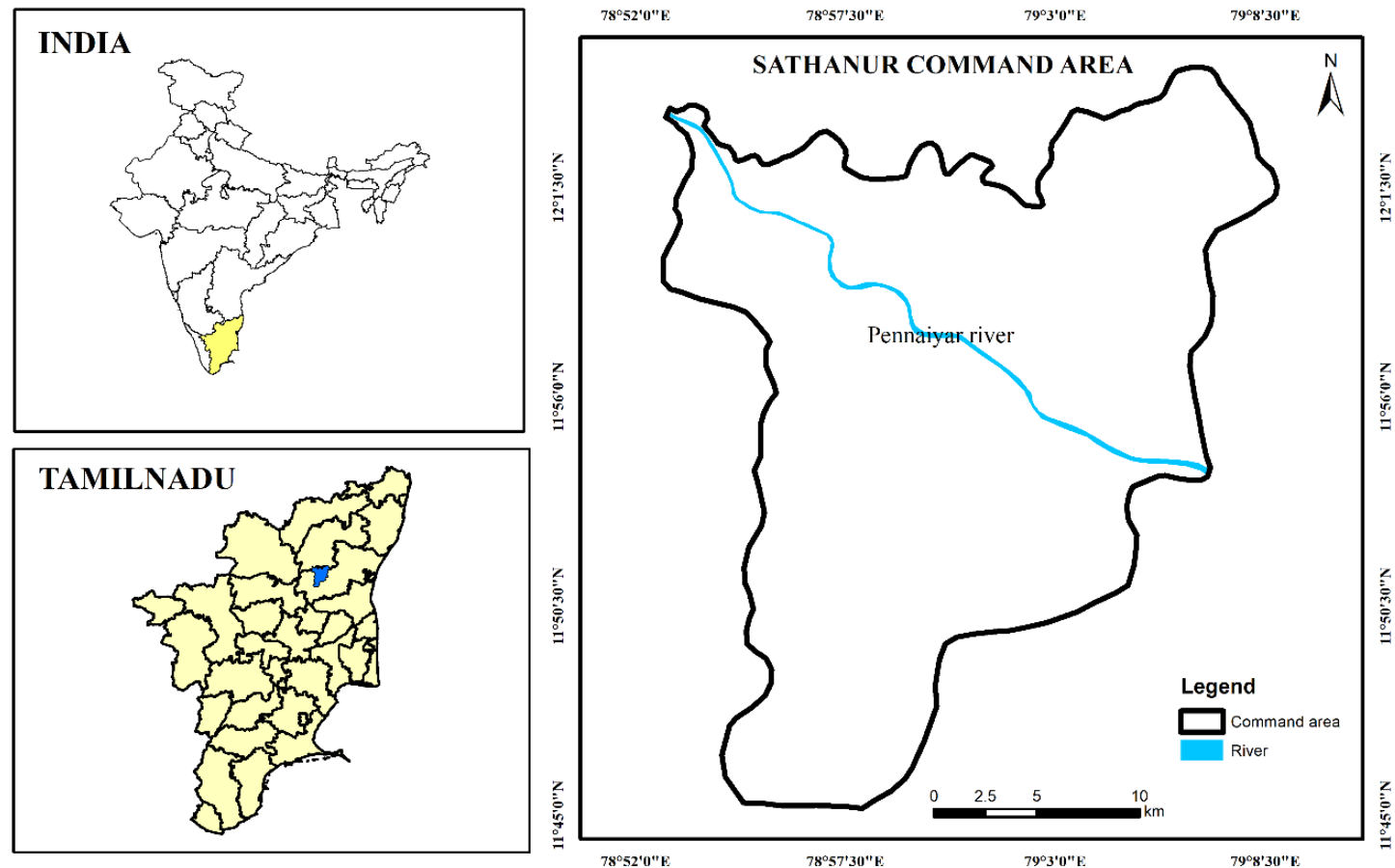

Figure 1. Sathanur Command Area Map

\subsection{Methodology}

Figure 2 is the flow chart that depicts the detailed methodology proposed for this work.

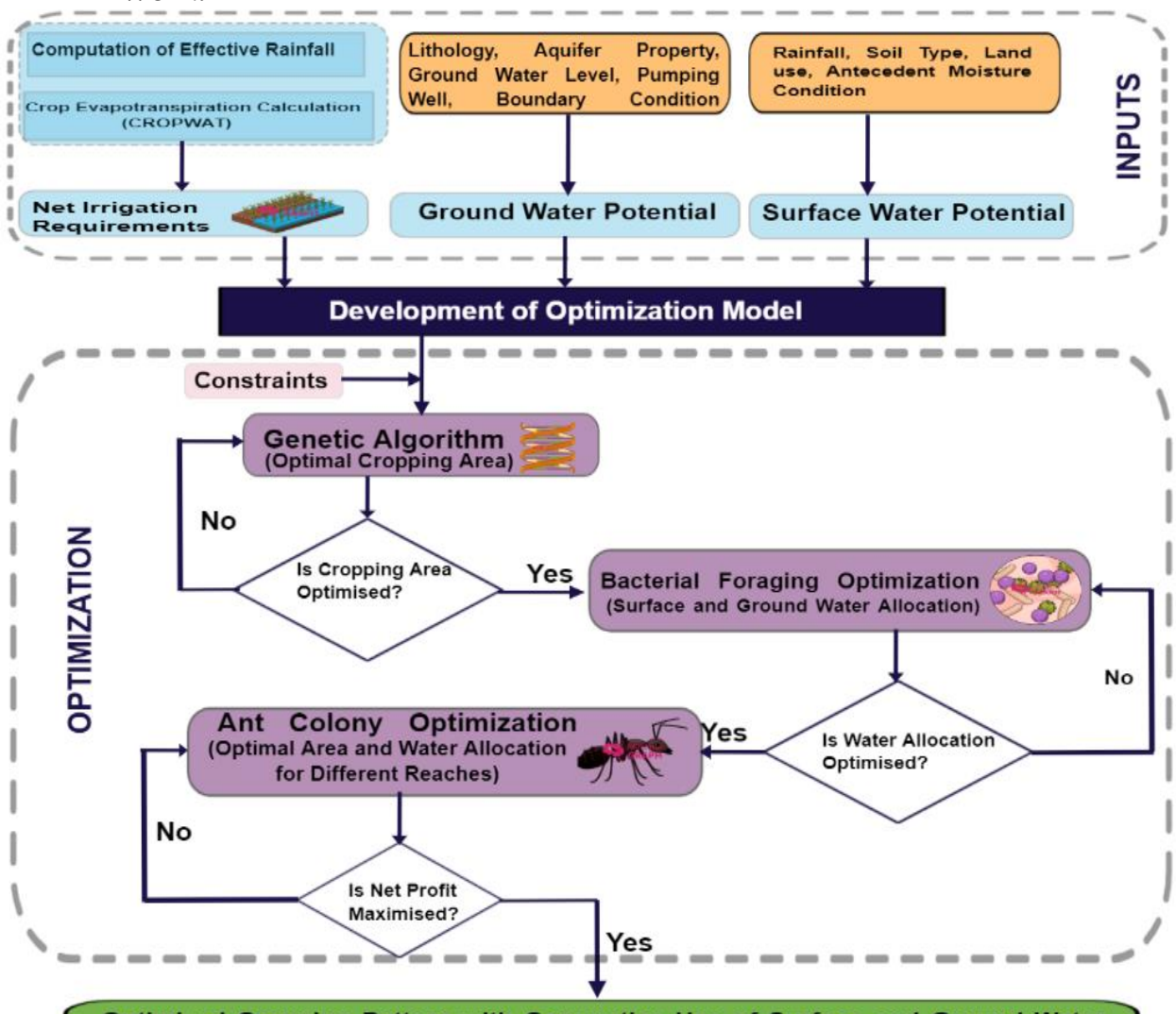

Optimized Cropping Pattern with Conunctive Use of Surface and Ground Water

Figure 2. Flowchart of the proposed work 


\subsection{Irrigation Water Requirements}

The net irrigation requirement (NIR) is referred as the amount of water required by a crop for augmenting the rainfall to meet the crop's evapotranspiration (ETC) without compromising the yield of the crop. There are several techniques are available to compute the reference crop evapotranspiration $\left(\boldsymbol{E} \boldsymbol{T}_{\mathbf{0}}\right)$ and crop evapotranspiration $(\boldsymbol{E T C})$ of the crop. [20][21]:

$$
E T c=K_{c} \times E T_{0}
$$

where $E T C$ represents the crop evapotranspiration in $\mathrm{mm} / \mathrm{day} ; K_{c}$ and $E T_{0}$ represent the crop coefficient and reference evapotranspiration in $\mathrm{mm} /$ day respectively. The following equation given by [22] is used to calculate the NIR of a crop:

$$
N I R=E T C-E R
$$

where $N I R$ is measured in $\mathrm{mm} / \mathrm{month}$ and $E R$ is the measurement of effective rainfall in $\mathrm{mm} / \mathrm{month}$.

CROPWAT is an effective decision tool proposed by FAO [23] for irrigation planning and management based on a daily water balance. It is used to compute $\mathrm{ET}_{0}$ and data required are duration of various crop growth stages, crop coefficients, date of sowing/planting, initial and final root depths, and crop yield response factors. In the case of paddy, the depth of water required for land preparation and puddling need to be specified [24]. Climatic data (monthly average) crop and soil data were used to estimate the ETc values and the NIR of crops in the command area.

\subsection{Estimation of Surface and Ground Water Potential}

The prediction of surface water volume for the rainfall depth from any catchment is possible with a well-established method called Soil Conservation Service Curve Number (SCS-CN). SCS-CN technique was proposed in the year 1964 by the USDA who determined that a single $\mathrm{CN}$ accounts for numerous factors that affect the runoff [25]. [26] suggests that the SCS-CN technique was a very useful method to estimate precipitation excess (runoff), by considering cumulative precipitation, antecedent soil moisture condition, land use, and land cover. The groundwater level fluctuation method recommended by the groundwater estimation committee [27] is widely used in the Indian context to calculate the net groundwater recharge for the command area during the monsoon season. Source [28] suggested that the groundwater level fluctuation method is useful in estimating the net groundwater recharge using the observed fluctuations in the groundwater level from 14 wells for a period of 15 years (2004-2018).

\subsection{Genetic Algorithm}

Genetic algorithms (GA) belong to a class of search algorithms that are used in function optimization [29]. The algorithms imitate the natural evaluation and survival of the fittest criteria in human beings. These types of algorithms are inspired by various conditions of selection, mutation, and crossover. The GA is an appropriate function optimizer because of its global character and flexibility. The process of GA consists of initialization, evaluation, selection, crossover, mutation, convergence, and stochastic operators [30]. The schematic procedure of GA proposed for this study is given in Figure 3. 


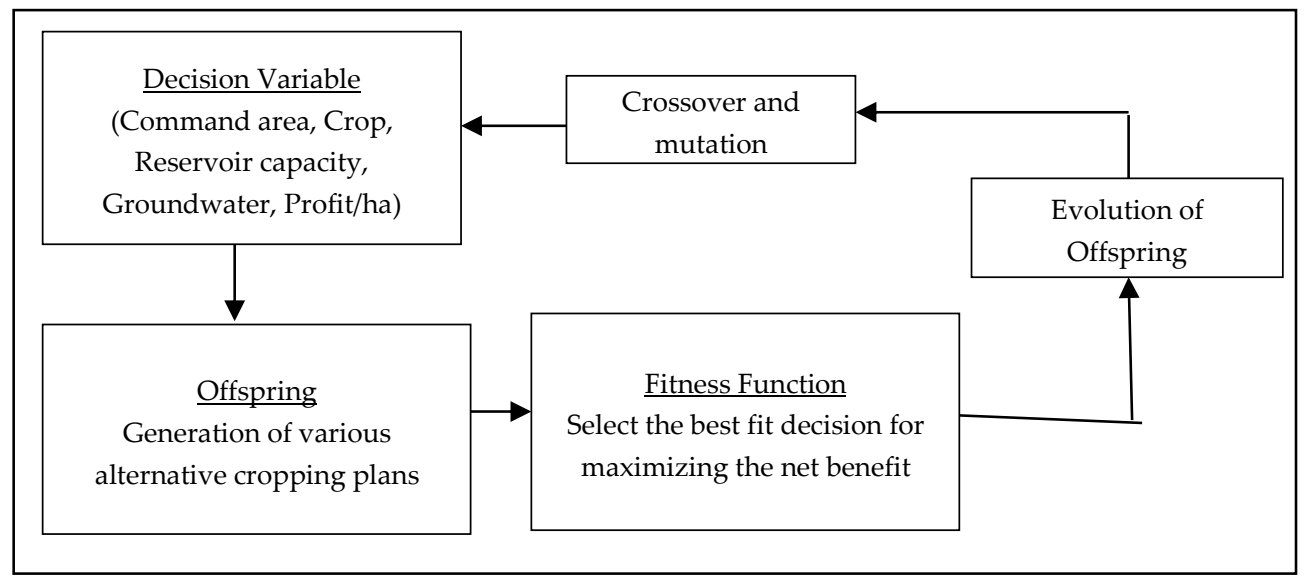

Figure 3. Schematic procedure of GA proposed for this study.

There are several parameters required to run a genetic algorithm. The GA algorithm uses the iterative technique to create an optimal solution to the given problem by appropriately adjusting the ideal parameter [31]. The optimization process using a genetic algorithm was carried out using a soft computing technique [32]. Source [33] has used an elitist strategy for obtaining the optimal solution using GA. The parameters used in the GA are population size, crossover, and mutation rates of 500, 0.9 , and 0.01 respectively to obtain the optimal solution. The elitist selection procedure with a generation gap of 0.98 is adopted.

\subsection{Optimization Model}

The main objective is to formulate an optimization model for maximum net returns by optimally utilizing the surface and groundwater resources (total water) for the crops that are grown (Farmer Preference Constraints) in the command area. The most important part of the optimization model is to assign the non-negative constraints to achieve the global optimum for the objective function. The non-negative constraints are incorporated because decision variables should not produce a negative value and the smallest value could be zero.

Maximize $\mathrm{Z}=\sum_{j=1}^{n} A_{j} \times P$

Subject to

$$
\begin{gathered}
\sum_{i=1}^{n} A_{j} W_{j} \leq T W R \\
\sum_{j=1}^{n} A_{j} \leq T C A \\
\sum T C A, T W R, A_{j} \geq 0
\end{gathered}
$$

where $A_{j}$ and $P$ is the area under irrigation and net return for $\mathrm{j}^{\text {th }}$ crop respectively. $W_{j}$ is the water requirement for $\mathrm{j}^{\text {th }}$ crop, $T W R$ is the total water (surface and groundwater) resources available and TCA is the total cultivable area under irrigation.

The main function of GA is to arrive an optimal cropping area of the Sathanur command with constraints such as type of crop, crop water requirement, available surface and groundwater resources. The output of GA is used as input to Bacterial Foraging Optimization (BFO) for optimizing the source (Surface and Groundwater) allocation for the conjunctive use of water.

\subsection{Bacterial Foraging Optimization (BFO) Algorithm}

In Bacterial foraging optimization technique presented by [34], a set of bacteria attempts to accomplish optimum threshold value by involving stages chemotaxis, swarm- 
ing, reproduction, elimination and dispersal. The main idea of BFO is imitating the chemotactic movement of virtual bacteria in the search domain. Each bacterium generates set of best possible values of parameters iteratively. Progressively, all the bacteria congregate to the global optimum threshold value. The bacteria have a choice either to tumble by a tumble or a tumble followed by a run/swim in the chemotaxis stage. In the process of swarming, each bacterium signals other bacterium to swarm together via attractants. To keep the swarm size constant, the least healthy bacteria die and the healthier bacteria is asexually split into two bacteria, which are then placed in the same location in the reproduction stage. Whereas in the final stage, any bacterium is either eliminated or dispersed from the set to a random space in the process of optimization. This stage mainly helps the bacteria to attaining the global optimum solution. If $i$ represents the bacterium position and $\mathrm{J}(\mathrm{i})$ is the objective function, then $\mathrm{J}(\mathrm{i})<0$; nutrient rich , $\mathrm{J}(\mathrm{i})=0$; neutral, and $\mathrm{J}(\mathrm{i})>0$; toxic. Bacteria tries to mount up the concentration of nutrient to find the minor values of J(i). And also, they try to find way out of neutral media and to avoid toxic substances. The BFO algorithm is modified to find the optimal allocation of surface and groundwater resources.

\subsubsection{Bacterial Foraging Optimization Algorithm for the Proposed Study}

The control parameters proposed of the Bacterial Foraging Optimization Algorithm for this study are (i) Number of bacterium $(S)=50$, (ii) Maximum number of steps $\left(\mathrm{N}_{s}\right)=$ 4, (iii) Number of chemotactic steps $\left(\mathrm{N}_{\mathrm{c}}\right)=100$, (iv) Number of reproduction steps $\left(\mathrm{N}_{\mathrm{re}}\right)=$ 4 , (v) Number of elimination-dispersal steps $\left(\mathrm{N}_{\mathrm{ed}}\right)=2$, (vi) Probability $\left(\mathrm{P}_{\mathrm{ed}}\right)=0.25$ and (vii) Step size $C(\mathrm{i})=0.1$

Step - 1: $S, N_{c}, N_{s}, N_{r e}, N_{e d}$, Ped (Intializing the Parameters) and the $C(i),(i=1,2 \ldots, S)$.

Choose the initial value for control variable $\left(\theta^{\mathrm{i}}\right)$ cropping area. The control variables $\left(\theta^{i}\right)$ are randomly distributed across the search space. Once the $\theta^{i}$ is computed, the $P$ value is updated automatically and reaches the termination when it reaches the maximum specified iterations.

Step - 2: 1= 1+1 (Elimination-Dispersal loop)

Step - 3: $\mathrm{k}=\mathrm{k}+1$ (Reproduction loop)

Step $-4: j=j+1$ (Chemo taxis loop)

(a) Chemo tactic step for bacterium ' $\mathrm{i}=1,2, \ldots \mathrm{S}^{\prime}$ as follows:

(b) Let $J(i, j, k, 1)=$ Compute water allocation

(c) $J(i, j, k, l)=J(i, j, k, l)+J_{c c}\left(\theta^{i}(j, k, l), P(j, k, l)\right)$

(d) To find better surface and groundwater allocation Jlast $=\mathrm{J}(\mathrm{i}, \mathrm{j}, \mathrm{k}, \mathrm{l})$

(e) Tumble: $\Delta(\mathrm{i}) \in \mathrm{Rp}$ with each element generate a random vector, $\mathrm{R}$ is a real number. Generate a random number on $[0,1]$ for the steps $\Delta \mathrm{m}(\mathrm{i}), \mathrm{m}=1,2, \ldots, \mathrm{p}$.

(f) Modify the water source allocation

$\theta^{i}(j+1, k, l)=\theta^{i}(j, k, l)+C(i) \frac{\Delta(i)}{\sqrt{\Delta^{T}(i) \Delta(i)}}$

This depicts step size C(i) for bacterium I in the direction of the tumble

(vii) Compute the updated water allocation $\mathrm{J}(\mathrm{i}, \mathrm{j}+1, \mathrm{k}, \mathrm{l})$

(viii) Swim.

Swim function is to allocate the positive increment of cropping area until satisfying the surface and groundwater availability

(ix) Take next bacterium (i+1) if $i \neq S$ (i.e., possibility of increment in area allocation for surface water and groundwater simultaneously)

Step - 5: If $j<\mathrm{N}_{c}$, repeat from step 3. Continue chemotaxis process, till all the surface and groundwater sources are allocated for each crop.

Step - 6:

(a) Jhealth (i) be the total allocation of water resources. Compute for the given $\mathrm{k}$ and $\mathrm{l}$, and for each $\mathrm{i}=1,2 \ldots, \mathrm{S}$, 


$$
J_{\text {health }}^{i}=\sum_{i=1}^{N_{c}+1} J(i, j, k, l)
$$

(b) The $\mathrm{S}_{\mathrm{r}}$ bacterium (allocated surface and groundwater) with the least productivity Jhealth values die and the healthy $\left(\mathrm{S}_{\mathrm{r}}\right)$ bacteria with the best values split.

Step - 7: If $k<\mathrm{N}_{\mathrm{re}}$, go to step 2. Once specified reproduction steps not reached.

Step - 8: Elimination-Dispersal

For $\mathrm{i}=1,2 \ldots, \mathrm{S}$ with probability $\mathrm{Ped}_{\mathrm{e}}$ to eliminate and disperse each bacterium in the random space on the optimization domain. If $1<\mathrm{Ned}_{\text {ed }}$ then go to step 1 , else end.

The BFO algorithm results in an optimal allocation of surface and groundwater resources considering the input from Genetic algorithm as optimum cropping pattern and the result of BFO is the input for Ant Colony Optimization (ACO) guided search algorithm to distribute resources to head, middle and tail command area to obtain the maximum net profit.

2.8. Ant Colony Optimization (ACO) For Optimal Conjunctive Use of Surface and Groundwater

The Ant Colony Optimization system[35] was first developed by the behaviour of ants to find the shortest route between food and nest. ACO is a branch of swarm intelligence and group of ants with its social behaviour used to solve optimization problems. While travelling ants deposit pheromones and the other ants follow in their trial. Each trial of an ant is strongly followed by pheromone deposit along possible path. The pheromone density during each trial is an indirect communication and reinforcement learning.

In this study, an ACO algorithm is developed to maximize the net profit from the distribution of surface and groundwater to the head, middle and tail reach of the command area for different crop seasons. The developed method is a mathematical optimization approach that uses a guided search technique. The search domain is flexible between the possible available surface and groundwater. The. The cropping area is discretized and assigned as ants for the search domain. The ants are allowed to move in the reaches of the head, middle and tail. The different sources of water (surface water and groundwater) are obtained from the BFO and are used for maximizing the net profit for the entire cropping season. Each ant will explore the possibility of maximizing the net profit through the area allocated in the head, middle and tail reach with the available surface water and groundwater.

The objective function of ACO for the net profit maximization and is given:

$$
\text { MAXIMIZE Z }=\sum_{\substack{i=1 \\ * N P(c p, k)}} \sum_{k=1}^{\text {seasons reaches sources }} C_{A}(i, j, k, c p)
$$

where, $\mathrm{Z}$ is the net profit function; $\mathrm{C}_{\mathrm{A}}$ is the area of the crop; $\mathrm{NP}$ is the net profit; $\mathrm{i}$ is the season varies from 1 to $3 ; j$ is the reaches (head, middle and tail); $k$ is the source of water supply (surface water and groundwater) and cp is the cropping pattern area (Paddy, sugarcane, groundnut, maize, grains and pulses)

The crop area is divided into a segment of varieties such as Paddy, sugarcane, groundnut, maize, grains and pulses. These crop areas are commanded in the reaches of the head, middle and tail in the form of discretized quantity. To facilitate the search by each ant, the surface and groundwater distribution for the different season is proportionally made for head, middle and tail reaches for the different crops. Three different policies are considered for the distribution of surface and groundwater and the details are given in Table 2. 
Table 2. Policies for distribution of Surface and Groundwater

\begin{tabular}{|c|c|c|c|c|c|}
\hline \multicolumn{6}{|c|}{ Policy - 1} \\
\hline & $\begin{array}{c}\text { Surface Water } \\
\text { Quantity }\left(\mathrm{Mm}^{3}\right)\end{array}$ & $\begin{array}{l}\% \text { of } \\
\text { SW }\end{array}$ & $\begin{array}{c}\text { Groundwater Quan- } \\
\text { tity } \\
\left(\mathrm{Mm}^{3}\right)\end{array}$ & $\%$ of GW & $\begin{array}{c}\text { Total Quantity } \\
\qquad\left(\mathrm{Mm}^{3}\right)\end{array}$ \\
\hline Season -1 & 207.67 & 100 & 0 & 0 & 207.67 \\
\hline Season -2 & 0 & 0 & 79.74 & 50 & 79.74 \\
\hline Season -3 & 0 & 0 & 79.74 & 50 & 79.74 \\
\hline \multicolumn{6}{|c|}{ Policy - 2} \\
\hline Season -1 & 103.84 & 50 & 0 & 0 & 103.84 \\
\hline Season -2 & 103.84 & 50 & 0 & 0 & 103.84 \\
\hline Season -3 & 0 & 0 & 159.48 & 100 & 159.48 \\
\hline \multicolumn{6}{|c|}{ Policy - 3} \\
\hline Season -1 & 124.60 & 60 & 15.95 & 10 & 140.55 \\
\hline Season -2 & 62.30 & 30 & 63.79 & 40 & 126.09 \\
\hline Season -3 & 20.77 & 10 & 79.74 & 50 & 100.51 \\
\hline
\end{tabular}

The possibility of visits made by an individual ant is based on the cropping pattern in the head, middle and tail reach and source of water (surface water and groundwater). Thus, each ant may have a different visiting order from other ants. Each ant must visit all the possible sources of water (surface water and groundwater).

The initial network of the ACO algorithm consists of several parameters such as $i, j$ and $\mathrm{k}$ representing the starting node, next node and ant respectively. Each ant in starting node $i$ is an agent who places pheromone on a visited path, and then chooses to visit the next node $j$ with a probability that is a function of the net profit and the pheromone density. $\tau_{\mathrm{ij}}$ represents the pheromone on edge $(i, j)$ at iteration $t$. It is updated according to the equation:

$$
\tau_{(\mathrm{i}, \mathrm{j})}=(1-\rho) \tau_{\mathrm{ij}}(t)+\Delta \tau_{i j}+\sum_{k=1}^{m} \Delta \tau_{(i j)}^{k}
$$

where, $(1-\varrho)$ represents the decay of pheromone between iterations $t$ and $t+1$, and

$$
\Delta \tau_{(\mathrm{ij})}=\sum_{k=1}^{m} \Delta \tau_{(i j)}^{k}
$$

where $\Delta \tau_{(\mathrm{ij})}^{\mathrm{k}_{(\mathrm{j}}}=$ pheromone change by ant $\mathrm{k}$ at $\mathrm{j} ; \mathrm{m}$ refers the total number of ants .The quantity of $\Delta \tau^{\mathrm{k}_{(\mathrm{ij})}}$ is given to be

$$
\Delta \tau_{(i j)}^{k}= \begin{cases}Q / L_{k} & \text { if ant } k \text { uses edge }(i, j) \text { in the iteration } t \\ 0 & \text { else }\end{cases}
$$

where $Q$ is refers (crop area) related to the quantity of trail made by ants, $L_{k}$ is the productivity $\left(\mathrm{Rs} / \mathrm{m}^{3}\right)$ for each ant $\mathrm{k}$. The third part is called elitist ant strategy, where, e is the elitist pheromone coefficient; $\Delta \tau^{\mathrm{e}_{(\mathrm{ij})}}$ is the pheromone laid by best ant at each $\Delta \tau^{\mathrm{e}_{(i \mathrm{j})}}=$ $\mathrm{Q} / \mathrm{Le}$, where $\mathrm{Le}_{\mathrm{i}}$ is the total tour length by an elitist ant. This leads to best solution with higher probability.

Next, the ant can decide the next node $\mathrm{j}$ from $\mathrm{i}$ by transition rule by the following equation:

$$
P_{i j}^{k}(t)=\frac{\left[\tau_{i j}(t)\right]^{\alpha}\left(\eta_{i j}\right)^{\beta}}{\sum k \in \text { allowed }\left[\tau_{i j}(t)\right]^{\alpha}\left(\eta_{i j}\right)^{\beta}}
$$

where defines the visibility $\eta_{\mathrm{ij}}$ is the ratio of water supplied and productivity. $\alpha$ is the relative importance of pheromone and $\beta$ is the visibility which control the relative importance. The translation probability is a tradeoff between the visibility, which is a greedy heuristic strategy, and the pheromone. 
The above steps are repeated for each set of cropping seasons to achieve the maximum net profit with conjunctive use of surface and groundwater. All mentioned computational experiments were coded in C++ using Microsoft Visual Studio 2015 platform.

\section{Results}

This section summarises and discusses the main findings of the work. To optimize the net profit of the Sathanur command area, a Hybrid optimization model was developed. The net return of each crop, Total water availability and the Net Irrigation Requirement were calculated and given as input parameters.

\subsection{Net Return of Crops}

The net profit of crops per hectare was estimated by including the market price of crops , crop yield and cost of production. The major crop expenses such as seed cost, land preparation cost and labour cost have been obtained from the Tamil Nadu Agriculture University and Agricultural Marketing Information Center (directorate of marketing and inspection), Thiruvannamalai District, Tamil Nadu, India. Profit per hectare for Paddy, Sugarcane, Groundnut, Maize, Pulses and Grains are 22156, 38000, 19136, 14000, 8000, 10000 rupees respectively.

\subsection{Total Water Availability}

The SCS runoff equation was developed to estimate the total storm runoff. Weighted $\mathrm{CN}-\mathrm{II}$ was estimated as 86 by taking into the consideration of hydrological soil group - B (moderately low runoff potential) and cultivated land area. The daily rainfall for 15 years was used to compute the daily runoff.

The total surface water is $282.22 \mathrm{Mm}^{3}$, which includes the reservoir capacity (207.67 $\mathrm{Mm}^{3}$ ) and the surface runoff of the command area. The quantity of surface water considered for the optimization model is $207.67 \mathrm{Mm}^{3}$ (reservoir capacity) and the groundwater quantity as $159.49 \mathrm{Mm}^{3}$ (obtained via the water table fluctuation method); thus, the total water available is $367.16 \mathrm{Mm}^{3}$ which is considered for the hybrid optimization model.

\subsection{Crop Water Requirement}

To estimate the crop water requirement (CWR) for each crop (paddy, sugarcane, groundnut, maize, grains, and pulses) CROPWAT was used and the values were $1.2 \mathrm{~m}, 2$ $\mathrm{m}, 0.42 \mathrm{~m}, 0.3 \mathrm{~m}, 0.2 \mathrm{~m}$, and $0.187 \mathrm{~m}$ respectively. Paddy and sugarcane have the highest CWR compared to other crops.

\subsection{Genetic Algorithm (GA)}

GA-based model was developed for optimizing the cropping area by taking into consideration of various constraints. The results of this optimization model reveal that there is a large variation in cropping area compared to the existing cropping pattern and the traditional cropping pattern and the values are depicted in Table 3.

Table 3. Optimal Cropping Area From GA

\begin{tabular}{|c|c|c|c|c|c|c|c|c|}
\hline & & \multicolumn{6}{|c|}{ Total Area (ha.) } & \multirow{2}{*}{$\begin{array}{c}\text { Net Profit } \\
\text { (Rs.) } \\
\text { (in Lakhs) }\end{array}$} \\
\hline & & Paddy & Sugarcane & Groundnut & Maize & Grains & Pulses & \\
\hline \multirow{3}{*}{$\begin{array}{c}\text { Policy - } \\
1\end{array}$} & Season -1 & 11000 & 300 & 4900 & 900 & 700 & 400 & 3638.82 \\
\hline & Season -2 & 2800 & 300 & 6300 & 4800 & 1600 & 2400 & 3751.72 \\
\hline & Season -3 & 0 & 300 & 17000 & 300 & 300 & 300 & 4400.66 \\
\hline \multirow{3}{*}{$\begin{array}{c}\text { Policy - } \\
2\end{array}$} & Season -1 & 1000 & 300 & 10000 & 3100 & 3000 & 800 & 2969.16 \\
\hline & Season -2 & 1500 & 300 & 9550 & 3050 & 3000 & 800 & 2986.83 \\
\hline & Season -3 & 0 & 300 & 17000 & 300 & 300 & 300 & 4400.66 \\
\hline \multirow{2}{*}{$\begin{array}{c}\text { Policy - } \\
3\end{array}$} & Season -1 & 4300 & 1600 & 9000 & 1700 & 900 & 700 & 3403.38 \\
\hline & Season -2 & 5200 & 1600 & 8900 & 1100 & 800 & 600 & 3978.24 \\
\hline
\end{tabular}




\begin{tabular}{|l|l|l|l|l|l|l|l|l|}
\hline & Season -3 & 0 & 1600 & 14400 & 1000 & 600 & 600 & 4017.31 \\
\hline
\end{tabular}

\subsection{Bacterial Foraging Optimization (BFO)}

The optimized cropping area obtained from the GA-based model for different seasons was given as input to BFO in-order to allocate the surface and groundwater conjunctively. This process involves all three scenarios and the results of the optimized surface and groundwater allocation for three seasons are shown in Table 4.1 to 4.3.

This analysis leads to some useful conclusions, most importantly the policy 1 and policy 2 allocations are based on either surface or groundwater. The optimized surface water allocated to season 1 is $144.12 \mathrm{Mm}^{3}$ and the corresponding area irrigated is 18125.4 ha. only and also a reduction in the net profit. Policy-3 leads to maximum conjunctive utilization of surface and groundwater for all three seasons through which net profit is increased considerably.

Table 4.1. Optimal water allocation for Policy 1

\begin{tabular}{|c|c|c|c|c|}
\hline \multicolumn{5}{|c|}{ Policy - 1 Season -1 } \\
\hline \multirow[t]{2}{*}{ Crop Type } & \multirow[t]{2}{*}{ Area (ha.) } & \multicolumn{2}{|c|}{ Water Supplied $\left(\mathrm{Mm}^{3}\right)$} & \multirow{2}{*}{$\begin{array}{c}\text { Net Profit (Rs.) } \\
\text { (in Lakhs) }\end{array}$} \\
\hline & & Surface Water & Groundwater & \\
\hline Paddy & 2808.04 & 55.24 & 0 & 622.15 \\
\hline Sugarcane & 3080.33 & 33.23 & 0 & 369.64 \\
\hline Groundnut & 3420.32 & 22.43 & 0 & 654.51 \\
\hline Maize & 3040.29 & 14.95 & 0 & 425.64 \\
\hline Grains & 2660.25 & 8.72 & 0 & 266.03 \\
\hline \multirow[t]{2}{*}{ Pulses } & 3116.16 & 9.55 & 0 & 249.29 \\
\hline & & \multicolumn{2}{|c|}{ Policy - 1 Season -2 } & \\
\hline Paddy & 5050.30 & 0 & 33.23 & 787.85 \\
\hline Sugarcane & 3080.33 & 0 & 12.32 & 766.29 \\
\hline Groundnut & 2226 & 0 & 8.90 & 553.76 \\
\hline Maize & 2491 & 0 & 7.47 & 453.36 \\
\hline Grains & 2623.50 & 0 & 5.25 & 341.06 \\
\hline \multirow[t]{2}{*}{ Pulses } & 2720.86 & 0 & 5.09 & 282.97 \\
\hline & & \multicolumn{2}{|c|}{ Policy - 1 Season -3} & \\
\hline Paddy & 0 & 0 & 0 & 0 \\
\hline Sugarcane & 3080.33 & 0 & 12.94 & 766.29 \\
\hline Groundnut & 6057.14 & 0 & 25.44 & 1506.82 \\
\hline Maize & 2968 & 0 & 8.90 & 540.18 \\
\hline Grains & 1987.50 & 0 & 3.975 & 258.38 \\
\hline Pulses & 4081.28 & 0 & 7.632 & 424.45 \\
\hline
\end{tabular}

Table 4.2. Optimal water allocation for Policy 2

\begin{tabular}{|c|c|c|c|c|}
\hline \multicolumn{5}{|c|}{ Policy - 2 Season -1 } \\
\hline Crop Type & Area (ha.) & \multicolumn{2}{|c|}{ Water Supplied $\left(\mathrm{Mm}^{3}\right)$} & $\begin{array}{c}\text { Net Profit (Rs.) } \\
\text { (in Lakhs) }\end{array}$ \\
\hline & & Surface Water & Groundwater & \\
\hline Paddy & 1936.14 & 38.09 & 0 & 328.97 \\
\hline Sugarcane & 2801.74 & 30.22 & 0 & 416.81 \\
\hline Groundnut & 2178.16 & 14.28 & 0 & 353.56 \\
\hline Maize & 2525.40 & 12.42 & 0 & \\
\hline
\end{tabular}




\begin{tabular}{|c|c|c|c|c|}
\hline Grains & 2399.13 & 7.87 & 0 & 239.91 \\
\hline Pulses & 1958.20 & 6 & 0 & 156.66 \\
\hline & & \multicolumn{2}{|c|}{ Policy -2 Season -2} & \\
\hline Paddy & 1929.13 & 34.16 & 0 & 427.42 \\
\hline Sugarcane & 2801.74 & 30.22 & 0 & 336.21 \\
\hline Groundnut & 2178.16 & 14.28 & 0 & 416.81 \\
\hline Maize & 2525.40 & 12.42 & 0 & 353.56 \\
\hline Grains & 2399.13 & 7.87 & 0 & 239.91 \\
\hline Pulses & 1958.20 & 6 & 0 & 156.66 \\
\hline & & \multicolumn{2}{|c|}{ Policy -2 Season -3} & 0.00 \\
\hline Paddy & 0 & 0 & 0.000 & 437.07 \\
\hline Sugarcane & 2801.74 & 0 & 18.44 & 3721.99 \\
\hline Groundnut & 14961.68 & 0 & 62.84 & 19.35 \\
\hline Maize & 106.33 & 0 & 0.32 & 20.73 \\
\hline Grains & 159.49 & 0 & 0.32 & 17.74 \\
\hline Pulses & 170.58 & 0 & 0.32 & \\
\hline
\end{tabular}

Table 4.3. Optimal water allocation for Policy 3

\begin{tabular}{|c|c|c|c|c|}
\hline \multicolumn{5}{|c|}{ Policy - 3 Season -1 } \\
\hline Crop Type & $\begin{array}{l}\text { Area } \\
\text { (ha.) }\end{array}$ & \multicolumn{2}{|c|}{ Water Supplied $\left(\mathrm{Mm}^{3}\right)$} & $\begin{array}{l}\text { Net Profit (Rs.) } \\
\text { (in Lakhs) }\end{array}$ \\
\hline & & Surface Water & Groundwater & \\
\hline Paddy & 3854.71 & 65.97 & 6.02 & 1362.39 \\
\hline Sugarcane & 2107.62 & 17.86 & 2.98 & 269.20 \\
\hline Groundnut & 2064.80 & 9.92 & 2.21 & 426.81 \\
\hline Maize & 2122.75 & 8.18 & 1.38 & 316.45 \\
\hline Grains & 4532.56 & 13.39 & 0.90 & 466.70 \\
\hline \multirow[t]{2}{*}{ Pulses } & 2352.26 & 5.95 & 0.77 & 198.04 \\
\hline & & \multicolumn{2}{|c|}{ Policy - 3 Season -2} & \\
\hline Paddy & 4035.10 & 25.79 & 27.85 & 1065.40 \\
\hline Sugarcane & 2102.88 & 6.57 & 9.83 & 306.12 \\
\hline Groundnut & 3705.21 & 10.04 & 8.69 & 833.81 \\
\hline Maize & 3142.37 & 7.19 & 5.04 & 510.49 \\
\hline Grains & 2508.46 & 4.59 & 2.99 & 265.97 \\
\hline \multirow[t]{2}{*}{ Pulses } & 2183.72 & 3.60 & 1.89 & 198.95 \\
\hline & & \multicolumn{2}{|c|}{ Policy - 3 Season -3} & \\
\hline Paddy & 0 & 0 & 0 & 0 \\
\hline Sugarcane & 2107.62 & 5.24 & 13.64 & 286.59 \\
\hline Groundnut & 9600 & 6.24 & 40.32 & 2561.60 \\
\hline Maize & 2359.33 & 4.80 & 7.078 & 566.04 \\
\hline Grains & 2205.12 & 1.48 & 5.184 & 313.65 \\
\hline Pulses & 1889.84 & 2.84 & 3.534 & 283.16 \\
\hline
\end{tabular}

\subsection{Ant Colony Optimization (ACO)}

The ACO allocates the surface and groundwater for the head, middle and tail reaches by taken into the account output of BFO. To ease the search by each ant, the surface and groundwater distribution for the different season is proportionally made for head, middle and tail reaches for the different types of crops. The results obtained from each Policy for the maximum net profit are tabulated in Table 5.1 to 5.3. 
The comparative results based on the output of BFO and ACO for all the seasons with different policies in terms of net profit is shown in Figure 4. Results show that the GABFO-ACO hybrid model provides maximum net benefits (Rs.33546.77 lakhs) than the GABFO hybrid model (Rs.27579.6 lakhs) for all the three seasons. The various trials were performed for each policy based on the productivity values and results are illustrated in Figure 5 .

It reveals that the maximum net profit is obtained from policy 3 through conjunctive use of surface and groundwater with maximum productivity comparing to other policies. The average productivity values from policies are $3.662 \mathrm{Rs} / \mathrm{m}^{3}$ (Policy 1), $3.440 \mathrm{Rs} / \mathrm{m}^{3}$ (Policy 2), 3.665 Rs $/ \mathrm{m}^{3}$ (Policy 3). Hence, the developed hybrid optimization is useful for a change of cropping pattern which in turn fetches more profit for the farmers of the Sathanur command area with conjunctive use of water.

Table 5.1 Optimal cropping pattern for Policy 1

\begin{tabular}{|c|c|c|c|c|c|c|c|}
\hline \multirow[b]{2}{*}{ Crop Type } & \multicolumn{3}{|c|}{ Area (ha.) } & \multicolumn{2}{|c|}{ Water Supplied $\left(\mathrm{Mm}^{3}\right)$} & \multirow{2}{*}{$\begin{array}{c}\text { Net Profit } \\
\text { (Rs.) } \\
\text { (in Lakhs) }\end{array}$} & \multirow{2}{*}{$\begin{array}{c}\text { Productivity } \\
\mathrm{Rs} / \mathrm{m}^{3}\end{array}$} \\
\hline & Head & Middle & Tail & $\begin{array}{c}\text { Surface } \\
\text { Water }\end{array}$ & Groundwater & & \\
\hline \multicolumn{8}{|c|}{ Policy - 1 Season -1 } \\
\hline Paddy & 7200 & 3600 & 200 & 171.14 & 0 & 2437.16 & 1.42 \\
\hline Sugarcane & 100 & 100 & 100 & 3.19 & 0 & 36 & 1.13 \\
\hline Groundnut & 3700 & 900 & 300 & 25.27 & 0 & 937.66 & 3.71 \\
\hline Maize & 300 & 300 & 300 & 4.37 & 0 & 126 & 2.89 \\
\hline Grains & 300 & 200 & 200 & 2.17 & 0 & 70 & 3.22 \\
\hline Pulses & 200 & 100 & 100 & 1.13 & 0 & 32 & 2.85 \\
\hline \multicolumn{8}{|c|}{ Policy -1 Season -2} \\
\hline Paddy & 900 & 900 & 1000 & 0 & 30.24 & 806.48 & 2.67 \\
\hline Sugarcane & 100 & 100 & 100 & 0 & 1.97 & 46.80 & 2.37 \\
\hline Groundnut & 2100 & 2100 & 2100 & 0 & 25.20 & 1567.24 & 6.22 \\
\hline Maize & 1700 & 1600 & 1500 & 0 & 14.40 & 873.60 & 6.07 \\
\hline Grains & 600 & 600 & 400 & 0 & 3.20 & 208 & 6.50 \\
\hline Pulses & 800 & 800 & 800 & 0 & 4.49 & 249.60 & 5.56 \\
\hline \multicolumn{8}{|c|}{ Policy - 1 Season -3} \\
\hline Paddy & 0 & 0 & 0 & 0 & 0 & 0 & 0 \\
\hline Sugarcane & 100 & 100 & 100 & 0 & 1.974 & 46.80 & 2.37 \\
\hline Groundnut & 5700 & 5700 & 5600 & 0 & 71.400 & 4229.06 & 5.92 \\
\hline Maize & 100 & 100 & 100 & 0 & 0.900 & 54.60 & 6.07 \\
\hline Grains & 100 & 100 & 100 & 0 & 0.600 & 39 & 6.50 \\
\hline Pulses & 100 & 100 & 100 & 0 & 0.561 & 31.20 & 5.56 \\
\hline
\end{tabular}

Table 5.2 Optimal cropping pattern for Policy 2

\begin{tabular}{|c|c|c|c|c|c|c|c|}
\hline \multirow{2}{*}{ Crop Type } & \multicolumn{3}{|c|}{ Area (ha.) } & \multicolumn{2}{|c|}{$\begin{array}{c}\text { Water Supplied } \\
\left(\mathrm{Mm}^{3}\right)\end{array}$} & \multirow{2}{*}{$\begin{array}{c}\text { Net Profit } \\
\text { (Rs.) } \\
\text { (in Lakhs) }\end{array}$} & \multirow[t]{2}{*}{$\begin{array}{c}\text { Productivity } \\
\text { Rs } / \mathrm{m}^{3}\end{array}$} \\
\hline & Head & Middle & Tail & $\begin{array}{c}\text { Surface } \\
\text { Water }\end{array}$ & $\begin{array}{l}\text { Ground- } \\
\text { water }\end{array}$ & & \\
\hline \multicolumn{8}{|c|}{ Policy - 2 Season -1} \\
\hline Paddy & 500 & 300 & 200 & 17.65 & 0 & 221.56 & 1.26 \\
\hline Sugarcane & 100 & 100 & 100 & 3.19 & 0 & 36 & 1.13 \\
\hline Groundnut & 4700 & 3300 & 2000 & 59.25 & 0 & 1913.60 & 3.23 \\
\hline Maize & 1900 & 900 & 300 & 12.68 & 0 & 434 & 3.42 \\
\hline
\end{tabular}




\begin{tabular}{|c|c|c|c|c|c|c|c|}
\hline Grains & 1500 & 1100 & 400 & 8.56 & 0 & 300 & 3.50 \\
\hline Pulses & 600 & 100 & 100 & 1.99 & 0 & 64 & 3.21 \\
\hline \multicolumn{8}{|c|}{ Policy - 2 Season -2} \\
\hline Paddy & 1050 & 250 & 200 & 21.97 & 0 & 332.34 & 1.51 \\
\hline Sugarcane & 100 & 100 & 100 & 3.19 & 0 & 36 & 1.13 \\
\hline Groundnut & 4800 & 3200 & 1550 & 55.20 & 0 & 1827.49 & 3.31 \\
\hline Maize & 1850 & 900 & 300 & 12.50 & 0 & 427 & 3.42 \\
\hline Grains & 1500 & 1100 & 400 & 8.56 & 0 & 300 & 3.5 \\
\hline Pulses & 600 & 100 & 100 & 1.99 & 0 & 64 & 3.21 \\
\hline \multicolumn{8}{|c|}{ Policy - 2 Season -3} \\
\hline Paddy & 0 & 0 & 0 & 0 & 0 & 0 & 0 \\
\hline Sugarcane & 100 & 100 & 100 & 0 & 1.97 & 46.80 & 2.37 \\
\hline Groundnut & 2920 & 1980 & 12100 & 0 & 71.40 & 4229.06 & 5.92 \\
\hline Maize & 100 & 100 & 100 & 0 & 0.90 & 54.60 & 6.07 \\
\hline Grains & 100 & 100 & 100 & 0 & 0.60 & 39 & 6.50 \\
\hline Pulses & 100 & 100 & 100 & 0 & 0.56 & 31.20 & 5.56 \\
\hline
\end{tabular}

Table 5.3 Optimal cropping pattern for Policy 3

\begin{tabular}{|c|c|c|c|c|c|c|c|}
\hline \multirow[b]{2}{*}{ Crop Type } & \multicolumn{3}{|c|}{ Area (ha.) } & \multicolumn{2}{|c|}{ Water Supplied $\left(\mathrm{Mm}^{3}\right)$} & \multirow[b]{2}{*}{$\begin{array}{c}\text { Net Profit } \\
\text { (Rs.) } \\
\text { (in Lakhs) }\end{array}$} & \multirow{2}{*}{$\begin{array}{c}\text { Productivity } \\
\mathrm{Rs} / \mathrm{m}^{3}\end{array}$} \\
\hline & Head & Middle & Tail & $\begin{array}{l}\text { Surface } \\
\text { Water }\end{array}$ & Groundwater & & \\
\hline \multicolumn{8}{|c|}{ Policy -3 Season -1} \\
\hline Paddy & 2700 & 1100 & 500 & 64.90 & 3.60 & 972.65 & 1.42 \\
\hline Sugarcane & 500 & 500 & 600 & 9.58 & 4.61 & 217.20 & 1.53 \\
\hline Groundnut & 4900 & 3200 & 900 & 41.58 & 4.80 & 1791.13 & 3.86 \\
\hline Maize & 500 & 800 & 400 & 5.88 & 1.20 & 254.80 & 3.60 \\
\hline Grains & 300 & 300 & 300 & 1.51 & 0.80 & 102 & 4.42 \\
\hline Pulses & 200 & 200 & 300 & 0.91 & 0.75 & 65.60 & 3.96 \\
\hline \multicolumn{8}{|c|}{ Policy -3 Season -2} \\
\hline Paddy & 2700 & 1900 & 600 & 38.42 & 27 & 1318.28 & 2.02 \\
\hline Sugarcane & 500 & 500 & 600 & 9.58 & 4.61 & 217.20 & 1.53 \\
\hline Groundnut & 2900 & 2800 & 3200 & 10.77 & 28 & 2104.96 & 5.43 \\
\hline Maize & 400 & 400 & 300 & 1.46 & 2.40 & 187.60 & 4.87 \\
\hline Grains & 200 & 200 & 400 & 0.97 & 1 & 95 & 4.82 \\
\hline Pulses & 200 & 200 & 200 & 0.91 & 0.56 & 55.20 & 3.76 \\
\hline \multicolumn{8}{|c|}{ Policy -3 Season -3} \\
\hline Paddy & 0 & 0 & 0 & 0 & 0 & 0 & 0 \\
\hline Sugarcane & 500 & 500 & 600 & 9.58 & 4.61 & 217.20 & 1.53 \\
\hline Groundnut & 4900 & 4700 & 4800 & 6.24 & 55.86 & 3519.11 & 5.67 \\
\hline Maize & 400 & 400 & 200 & 2.61 & 1.20 & 156.80 & 4.12 \\
\hline Grains & 200 & 200 & 200 & 0.97 & 0.60 & 69 & 4.39 \\
\hline Pulses & 200 & 200 & 200 & 0.91 & 0.56 & 55.20 & 3.76 \\
\hline
\end{tabular}




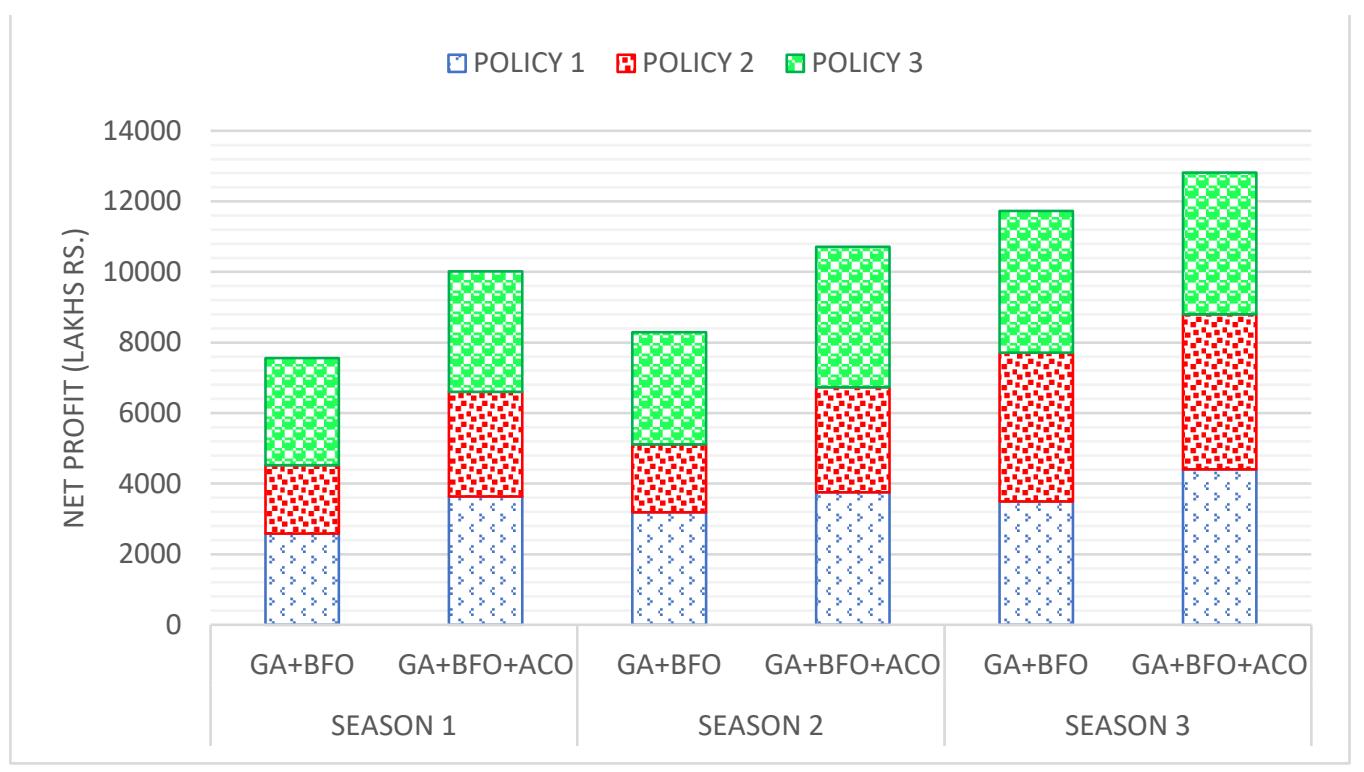

Figure 4. Comparison of Net Profit values of BFO and ACO for different scenarios

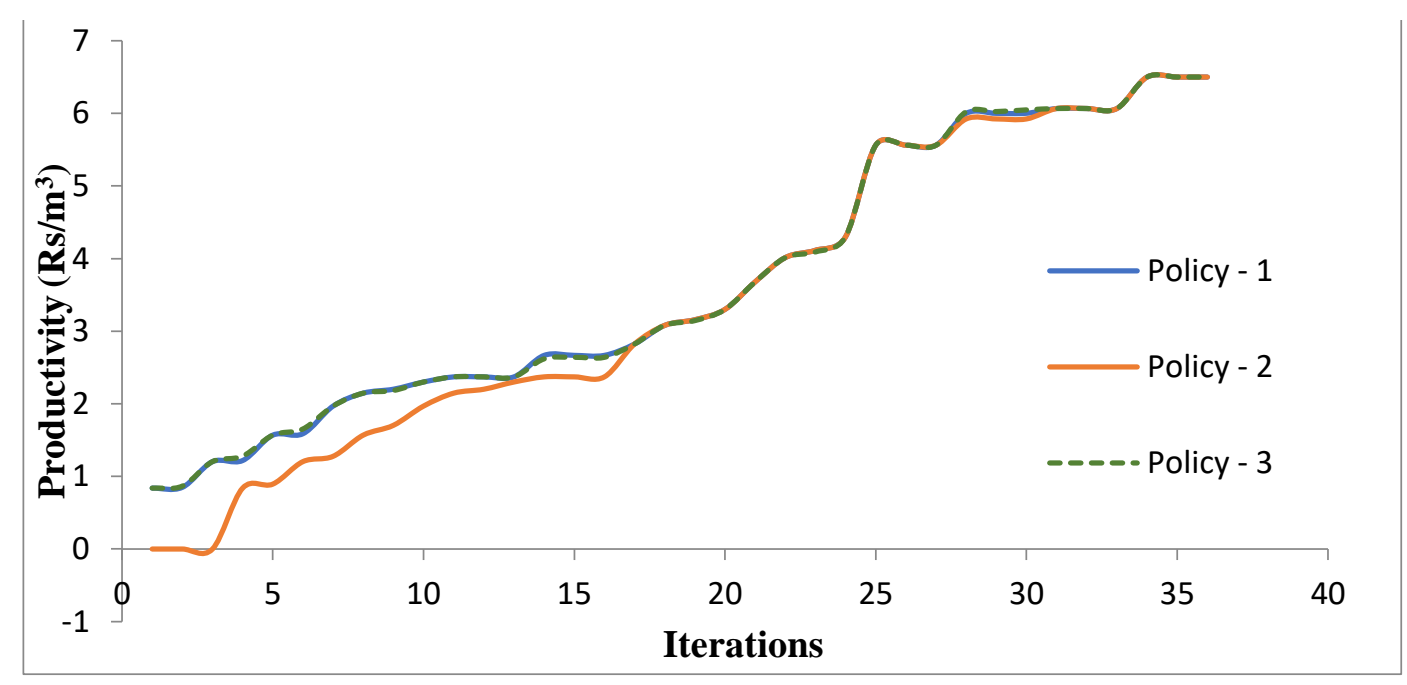

Figure 5. Productivity values for different scenarios

\section{Discussion}

Nowadays, the farmers in the command area are not getting enough net benefits from the existing cropping pattern due to following reasons: (i) Conjunctively not utilizing the available water resources (ii) traditional cropping pattern. The present study develops a framework for optimal conjunctive use of water resources for maximizing the net returns in a Sathanur command area. Furthermore, the results also agreed to previous studies $[13,16]$ that hybridization of meta-heuristic algorithms provides the maximum net benefits. Unlike the past studies [12,17] , In this study hybridization of three meta-heuristic algorithms (GA, BFO and ACO) for optimizing the cropping area, conjunctive water allocation and the net returns for different reaches. Net returns from $\mathrm{GA}+\mathrm{BFO}+\mathrm{ACO}$ model was found to be $21.64 \%$ higher than GA + BFO model. The productivity value of policy 3 was $6.54 \%$ greater than the policy 2 whereas policy 1 was $6.45 \%$ greater. Thus, the optimal 
cropping pattern developed in this study by considering conjunctive use is very promising for enhancing the farmers' net income as well as for the conservation of water resources in the command area due to the foraging behaviour and guiding mechanism of the developed hybrid optimization model (GA-BFO-ACO). Finally, the hybridization of meta-heuristic algorithm developed in this study can be adopted in other reservoir commands across the globe.

Author Contributions: For research articles with several authors, a short paragraph specifying their individual contributions must be provided. The following statements should be used "Conceptualization, K.M.,S.R.; methodology, K.M.,S.R.; software, K.M.,S.R. and B.R.; validation, K.M.,S.R. and B.R.; investigation, H.R.P.; X.X.; resources, S.K.,B.L.; data curation, S.K.,B.L.; writing-original draft preparation, K.M.; writing - review and editing, S.R.; supervision, S.R.; All authors have read and agreed to the published version of the manuscript.

Funding: This research received no external funding

Acknowledgments: The authors are thankful to Public Works Department and Agriculture Department, Tiruvannamalai and Institute for Water Studies, Chennai for providing necessary data to carry out this research work.

Conflicts of Interest: The authors declare no conflict of interest.

\section{References}

1. Yearbook, F.A.O.S. World food and agriculture. Food Agric. Organ. United Nations, Rome 2013, 15.

2. Jongman, B.; Hochrainer-Stigler, S.; Feyen, L.; Aerts, J.C.J.H.; Mechler, R.; Botzen, W.J.W.; Bouwer, L.M.; Pflug, G.; Rojas, R.; Ward, P.J. Increasing stress on disaster-risk finance due to large floods. Nat. Clim. Chang. 2014, 4, $264-268$.

3. (WBCSD), W.B.C. for S.D. Facts and trends: Water 2006.

4. Singh, A.; Panda, S.N.; Saxena, C.K.; Verma, C.L.; Uzokwe, V.N.E.; Krause, P.; Gupta, S.K. Optimization Modeling for Conjunctive Use Planning of Surface Water and Groundwater for Irrigation. J. Irrig. Drain. Eng. 2016, 142, 04015060.

5. Singh, A. Conjunctive use of water resources for sustainable irrigated agriculture. J. Hydrol. 2014, 519, 1688-1697.

6. Tyagi, N.K.; Narayana, V.V.D. Water Use Planning for Alkali Soils Under Reclamation. J. Irrig. Drain. Eng. 1984, 110, 192207.

7. Khare, D.; Jat, M.K.; Sunder, J.D. Assessment of water resources allocation options: Conjunctive use planning in a link canal command. Resour. Conserv. Recycl. 2007, 51, 487-506.

8. Matsukawa, J.; Finney, B.A.; Willis, R. Conjunctive-Use Planning in Mad River Basin, California. J. Water Resour. Plan. Manag. 1992, 118, 115-132.

9. Vedula, S.; Mujumdar, P.P.; Chandra Sekhar, G. Conjunctive use modeling for multicrop irrigation. Agric. Water Manag. 2005, 73, 193-221.

10. Benedini, M. Developments and possibilities of optimization models. Agric. Water Manag. 1988, 13, 329-358.

11. Karamouz, M.; Kerachian, R.; Zahraie, B. Monthly Water Resources and Irrigation Planning: Case Study of Conjunctive Use of Surface and Groundwater Resources. J. Irrig. Drain. Eng. 2004, 130, 391-402.

12. Varade, S.; Patel, J.N. Determination of Optimum Cropping Pattern Using Advanced Optimization Algorithms. J. Hydrol. Eng. 2018, 23, 05018010.

13. Kumar, V.; Yadav, S.M. Optimization of Cropping Patterns Using Elitist-Jaya and Elitist-TLBO Algorithms. Water Resour. Manag. 2019, 33, 1817-1833.

14. Kumar, V.; Yadav, S.M. Self-adaptive multi-population-based Jaya algorithm to optimize the cropping pattern under a constraint environment. J. Hydroinformatics 2020, 22, 368-384.

15. Rath, A.; Samantaray, S.; Swain, P.C. Optimization of the cropping pattern using Cuckoo search technique; Springer International Publishing, 2019; Vol. 374; ISBN 9783030031312. 
16. Rath, A.; Swain, P.C. Optimal allocation of agricultural land for crop planning in Hirakud canal command area using swarm intelligence techniques. ISH J. Hydraul. Eng. 2018, 1-13.

17. Mohammadrezapour, O.; Yoosefdoost, I.; Ebrahimi, M. Cuckoo optimization algorithm in optimal water allocation and crop planning under various weather conditions (case study: Qazvin plain, Iran). Neural Comput. Appl. 2019, 31, 1879-1892.

18. Safavi, H.R.; Falsafioun, M. Conjunctive use of surface water and groundwater resources under deficit irrigation. J. Irrig. Drain. Eng. 2017, 143, 1-9.

19. Kannan, M.G.V. Paddy Yield Estimation Using Remote Sensing and Geographical Information System. J. Mod. Biotechnol. 2012, 1, 26-30.

20. Allen, Richard G and Pereira, Luis S and Raes, Dirk and Smith, M. and others Crop evapotranspiration-Guidelines for computing crop water requirements-FAO Irrigation and drainage paper 56. Fao, Rome 1988, 300, D05109.

21. Jensen, M.E.; Burman, R.D.; Allen, R.G. Evapotranspiration and irrigation water requirements.; ASCE, 1990.

22. Smajstrla, Allen George and Zazueta, F. Estimating crop irrigation requirements for irrigation system design and consumptive use permitting; University of Florida Cooperative Extension Service, Institute of Food and Agriculture Sciences, EDIS., 1998;

23. Smith, M. CROPWAT: A computer program for irrigation planning and management; 46th ed.; Food \\& Agriculture Org, 1992;

24. Islam, S.; Talukdar, B. Crop yield optimization using genetic algorithm with the CROPWAT model as a decision support system. Int. J. Agric. Eng. 2014, 7, 7-14.

25. USDA, S. National Engineering Handbook, Sec. 4 Hydrology. Washingt. DC 1964.

26. Mishra, S.K.; Singh, V.P. SCS-CN Method. In Soil Conservation Service Curve Number (SCS-CN) Methodology; Springer Netherlands: Dordrecht, 2003; pp. 84-146 ISBN 978-94-017-0147-1.

27. Methodology, G.R.E. Report of the groundwater resource estimation committee. Minist. Water Resour. Gov. India, New Delhi $1997,107$.

28. Scanlon, B.R.; Healy, R.W.; Cook, P.G. Choosing appropriate techniques for quantifying groundwater recharge. Hydrogeol. J. 2002, 10, 18-39.

29. Holland, J.H. Adaptation in Natural and Artificial Systems; MIT Press: Cambridge, MA, USA, 1992; ISBN 0-262-58111-6.

30. Whitley, D. A genetic algorithm tutorial. Stat. Comput. 1994, 4, 65-85.

31. Dobslaw, F. A parameter-tuning framework for metaheuristics based on design of experiments and artificial neural networks. World Acad. Sci. Eng. Technol. 2010, 64, 213-216.

32. Sahoo, B.; Walling, I.; Deka, B.C.; Bhatt, B.P. Standardization of reference evapotranspiration models for a subhumid valley rangeland in the Eastern Himalayas. J. Irrig. Drain. Eng. 2012, 138, 880-895.

33. Ghosh, A.; Dehuri, S. Evolutionary Algorithms for Multi-Criterion Optimization: A Survey. Int. J. Comput. Inf. Sci. 2004, 2, 38-57.

34. Passino, K.M. Biomimicry of bacterial foraging for distributed optimization and control. IEEE Control Syst. Mag. 2002, 22, 5267.

35. Meuleau, N.; Dorigo, M. Ant colony optimization and stochastic gradient descent. Artif. Life 2002, 8, $103-121$. 